\title{
Genderově motivované a sexuální obtěžování na středních školách: Hranice vhodného chování ${ }^{1}$
}

\author{
Gender Based and Sexual Harassment at High Schools: \\ the Limit of Appropriate Behavior
}

Irena Smetáčková, Petr Pavlík

\begin{abstract}
The article discusses borders between proper and improper behaviour of teachers towards high school students. Based on a survey of 1,237 students, we show what types of teacher behaviour sexual harassment characteristics students consider unpleasant and how frequent their experiences with such behaviour are. One part of the survey instrument was inspired by SEQ which allows to compare Czech results with frequency and awareness of sexual harassment abroad. The comparison indicates about the same occurrence of sexual harassment in Czech high schools. However, it also shows significantly lower sensitivity to its inappropriateness. This translates to higher tolerance of Czech students to teacher behaviour with sexual harassment characteristics. Girls were significantly more critical than boys. Students were also significantly more critical when behaviour was considered in a concrete situational context. Research findings have implications for forms of sexual harassment prevention and also open methodological questions concerning the use of so-called scripts.
\end{abstract}

KEY WORDS sexual harassment, gender harassment, high school, gender sensitivity

\section{Úvod: zaměření a východiska článku}

V roce 2009 byly realizovány dva první české výzkumy sexuálního obtěžování vysokoškolaček a vysokoškoláků ze strany jejich vyučujících. ${ }^{2}$ Jejich prostřednictvím byla prokázána relevance tohoto fenoménu $\mathrm{v}$ českém vzdělávacím systému, a zároveň byla prohloubena

Sociálni studia. Katedra sociologie FSS MU, 3/2012. S. 11-30. ISSN 1214-813X.

1 Článek vznikl v rámci projektu „Sexuální obtěžování ve středoškolském prostředí: výskyt a vnímání“, který byl financován jako specifický vysokoškolský výzkum Fakulty humanitních studií Univerzity Karlovy, číslo projektu 261701, a v rámci projektu „Nerovné podmínky škol - nerovné šance žáků“ podpořeného Grantovou agenturou České republiky, číslo projektu GAČR P407-111556. V článku jsou využívány výsledky dosažené v projektu „Sexuální obtěžování na vysokých školách: výskyt a vnímáni““, který byl podpořen v rámci Národního programu výzkumu II, číslo projektu 2E08058.

2 Výzkum nesl název „Sexuální obtěžování na vysokých školách: výskyt a vnímání“. Tým tvořili P. Pavlík, I. Smetáčková a K. Kolářová a dále šest pomocných výzkumnic (K. Cidlinská, E. Juračková, L. Slavíková, L. Vrbová, částečně M. Hynková a M. Fucimanová). Ve výzkumu jsme analyzovali dvě skupiny dat, z nichž jedna byla získána prostřednictvím rozhovorů a druhá prostřednictvím dotazníku. Dotazníkového šetření se zúčastnilo 832 studentů a studentek jedenácti 
teoretická diskuse o jeho obsahovém vymezení i metodologickém uchopení. Vzhledem k poměrně velkému množství odborných článků a konferenčních příspěvků na toto téma prezentovaných v uplynulých dvou letech považujeme pojem sexuální obtěžování za etablovaný a nebudeme se jím proto v tomto textu zevrubněji zaobírat. Pouze ve stručnosti nastíníme, s jakým pojetím sexuálního obtěžování zde budeme pracovat.

Sexuální obtěžování pro nás představuje chování, které splňuje následující tři podmínky: a) dochází k němu zpravidla mezi osobami s nerovným mocenským postavením; b) vzhledem ke kontextu neadekvátně zdůrazňuje skutečnost, že zúčastněné osoby jsou ženami či muži a jejich vztah tím činí nepřiměřeně sexualizovaný; c) má pro obtěžovanou osobu negativní důsledky v oblasti psychické, somatické, studijní, sociální aj. ${ }^{3}$ Toto pojetí vychází ze socio-kulturních výkladových modelů, které akcentují genderovou perspektivu (viz Smetáčková a Pavlík 2011). Podle této skupiny výkladových modelů je sexuální obtěžování strukturální problém, který vyrůstá z dichotomie a biologizace feminity a maskulinity, a je tak vyhroceným projevem polarizace a androcentrismu genderového řádu (Uggen a Blackstone 2004; Tangri a Hayes 1997). Ten tvoří společný jmenovatel pro dílčí typy projevů, které lze pod sexuální obtěžování zařadit. Při členění typů chování využíváme přístup L. Fitzgerald (1995), která za sexuální obtěžování považuje sexuální nátlak, sexuální pozornost a užívání genderových stereotypů. Tato klasifikace tvoří platformu standardizovaného dotazníku SEQ (Sexual Experience Questionnaire), který v současné době patří k nejvíce používaným výzkumným nástrojům $\mathrm{v}$ dané oblasti. Jeho zněním jsme se inspirovali při přípravě vlastních dotazníků pro mapování sexuálního obtěžování na vysokých a středních školách.

Ve výzkumu sexuálního obtěžování na vysokých školách jsme ve shodě se zahraničními výzkumy dospěli ke zjištění, že studentské zkušenosti s obtěžujícím chováním ze strany vyučujících jsou relativně četné. Zároveň však výzkum ukázal, že větší část těchto zkušeností studující nepovažují přímo za sexuální obtěžování, respektive dané chování nespojují s tímto pojmem. Z toho vyplývá, že studentské vymezení sexuálního obtěžování je výrazně užší v porovnání $\mathrm{s}$ tím, jaké chování bývá pod toto označení zařazováno v rámci odborných definic. Ačkoliv rozdíl mezi odbornými a právními definicemi sexuálního obtěžování a subjektivním vymezením konkrétních aktérů/aktérek je prokázán rovněž v zahraničních výzkumech, v českém prostředí se ukazuje jako výrazně vyšší. ${ }^{4}$ Důvody pro to vidíme dva - jed-

vysokých škol. Ve stejném období byl realizován výzkum sexuálního obtěžování na vysokých školách Sociologickým ústavem AV ČR (Vohlídalová 2009).

3 Pro ilustraci uvádíme dvě konkrétní definice, z nichž vycházíme: „Chování vyvolávající nepřátelské prostředí a vedoucí k zastrašování či ponižování, které je spojené se skutečností, že daný člověk je ženou či mužem“ (Corr a Jackson 2001); „,chování vztažené k sexualitě a/nebo k genderu, které je pro daného člověka nevítané a ubližující“ (Paludi 1997).

4 V definicích sexuálního obtěžování náležejících do socio-kulturních výkladových modelů lze rozpoznat čtyři dílčí linie, které se liší zejména tím, jak silně a jakým způsobem využívají subjektivněobjektivní prizma: 1) odborné definice - sexuální obtěžování je vymezeno a priori a jeho reálný výskyt není závislý na tom, zda aktéři označí dané chování za sexuální obtěžování; 2) laické definice - sexuální obtěžování je vymezeno samotnými aktéry a pouze takové chování, které odpovídá jejich významu, může být považováno za sexuální obtěžování; 3) objektivní definice sexuální obtěžování nemusí v člověku vyvolávat negativní pocity a odpor, i takové chování, které 
ním je absence problematiky interpersonálních hranic a moci ve veřejné diskusi, druhým je sémantický posun mezi anglickým pojmem „sexual“ a českým pojmem sexuální.

$\mathrm{V}$ důsledku prvního faktoru panuje $\mathrm{v}$ české společnosti tendence ke zdůrazňování role individuálních zájmů a dispozic při budování mezilidských vztahů na úkor jejich sociálně-strukturálních podmínek. To pak vede $\mathrm{k}$ přehlížení mocenských asymetrií a jejich vlivu na průběh vztahů a konkrétně v souvislosti se sexuálním obtěžováním $\mathrm{k}$ jeho bagatelizaci. ${ }^{5}$

Druhým zmiňovaným faktorem je pojmové zúžení. Adjektivum sexuální odkazuje v češtině výhradně $\mathrm{k}$ aktivitám sexuální povahy, zatímco $\mathrm{v}$ angličtině má navíc význam pohlavně (respektive genderově) diferenciační. Z hlediska typů chování, které pod dané označení náleží, je anglický pojem výrazně širší. Zahrnuje i takové projevy, které souvisí s utvářením nepřátelského prostředí $\mathrm{v}$ důsledku kontextuálně neadekvátního zdůrazňování skutečnosti, že daný člověk je mužem či ženou, tzn. sexualizovanou bytostí a/nebo bytostí s určitými charakteristikami odvozenými na principu generalizace z genderových stereotypů. Na základě výzkumu obtěžujícího chování na vysokých školách jsme proto začali plédovat za uživání označení genderově motivované a sexuálni obtěžování namísto dosud dominantního označení sexuální obtěžování. ${ }^{6}$ Použití pojmu genderově motivované obtěžování přesněji vystihuje šiřrku projevů v daném fenoménu, což je významné jak metodologicky, tak osvětově.

Ze zmiňovaného výzkumu obtěžování na vysokých školách vyplynulo nejen, že s určitými projevy překračování hranic běžného pedagogického vztahu ze strany vyučujících mají zkušenost téměř dvě třetiny studujících, ale také, že se s tímto fenoménem setkali již v průběhu středoškolského studia. Podle 81 \% vysokoškoláků a vysokoškolaček je sexuální obtěžování (přímo s použitím tohoto označení) součástí interakcí na středních školách. Rozhodli jsme se proto v navazujícím výzkumu ověřit, nakolik tato reflexe odpovídá reálnému stavu.

V tomto článku chceme stručně představit výsledky dotazníkového šetření mezi studujícími na středních školách, přičemž přednostně se budeme věnovat zjištěním, která vyplynula z posuzování tzv. scénářu. Scénáře představují nástroj pro zjišt'ování pohledu respondentů/respondentek na jevy zasazené do reálného situačního kontextu, v němž se vyskytuje řada dílčích prvků v dynamických vztazích. Scénářem se míní konkrétní reálná situace, v níž je př́tomno chování odpovídající některému z projevů genderově motivovaného a sexuálního obtěžování. Situace je relativně komplexně popsána a dále je k ní připojena sada otázek směřujících $\mathrm{k}$ hodnocení různých aspektů události, chování zmíněných aktérů a vlastních pocitů. Na základě zahraničních studií i vlastních výzkumných zkušeností považujeme scénáře $\mathrm{z}$ metodologického hlediska za velice prŕínosné, nebot' rozšiřují škálu dílčích technik pro reflexi sociálních jevů. Zvláště užitečné se jeví v př́ípadě takových sociálních jevů, jako je sexuální obtěžování, o nichž v široké veřejnosti neexistuje hlubší povědomí - uvědomování existence těchto jevů je nízké nebo porozumění jim je silně založeno na stereotypech.

je aktéry přijímáno, může splňovat znaky sexuálního obtěžování; 4) subjektivní definice - sexuální obtěžování je pouze takové chování, které v jedinci vzbuzuje nepř́ijemné a nesouhlasné reakce.

5 Př́kladem bagatelizace je užívání označení harašení namísto obtěžování.

6 Argumentaci podrobněji rozvádíme v článku publikovaném v Sociologickém časopisu (Smetáčková a Pavlík 2011). 
V článku tak spojujeme představení výsledků výzkumu s metodologickou diskusí o použitém nástroji.

\section{Představení výzkumu}

Výzkum, ze kterého $\mathrm{v}$ tomto textu vycházíme, byl realizován $\mathrm{v}$ roce $2010 \mathrm{~s}$ cílem zmapovat zkušenosti středoškolských studentek a studentů s projevy sexuálního obtěžování ze strany svých vyučujících. Protože chování s charakteristikami sexuálního obtěžování je poměrně rozmanité, pokud jde o míru zvýznamnění sexuality i z hlediska závažnosti, a existuje řada projevů, které nemají genderový a/nebo sexuální rozměr, ale přesto překračují hranice optimálního pedagogického vztahu a lze je považovat za obtěžující (Plaut 2008; Pianta 1999), zaměřovali jsme se nejen na genderově motivované a sexuální obtěžování, ale také na jiné formy obtěžování, a zjišt'ovali jsme, nakolik spolu souvisí a zda tvoří postupně gradující škálu projevů. Věnovali jsme se přitom výlučně typům chování, jejichž společným jmenovatelem je snaha využít či dokonce zvýšit mocenskou převahu, kterou mají vyučující nad studujícími, což vede k získání profesní či osobní výhody. Výzkumné otázky zněly: 1) Jak časté mají studenti a studentky různých typů středních škol zkušenosti s jednotlivými učitelskými projevy překračujícími rámec pedagogického vztahu? 2) Nakolik toto chování sami považují za obtěžující? 3) V jakém prostředí k obtěžujícímu chování nejčastěji dochází? 4) Kdo jsou obvykle hlavní aktéŕi obtěžujícího chování? 5) Jaké reakce obtěžující chování u studujících vyvolává?

Projekt navazoval na výše zmíněný výzkum sexuálního obtěžování na vysokých školách uskutečněný v letech 2008-2009, v rámci kterého jsme kombinovali dotazníkové šetrení (832 respondentů/respondentek) a hloubkové polostrukturované rozhovory (40 respondentů/ respondentek). Inspirace byla nejen metodologická, ale i faktická, nebot' v rámci vysokoškolského výzkumu řada studujících indikovala zkušenosti se sexuálním obtěžováním již v průběhu středoškolského studia. Bylo proto vhodné ověřit, nakolik se zmíněné výsledky kryjí s realitou a jak sexuální obtěžování vnímají stř̌edoškolské studentky a studenti.

Srovnání některých údajů o středních a vysokých školách umožnila podobnost výzkumného nástroje použitého v obou šetřeních. Dotazník použitý ve výzkumu na vysokých školách obsahoval baterie položek zaměřených na aktérství, situační kontext a hodnocení potenciálně obtěžujících situací a dále sadu otázek inspirovaných standardizovaným dotazníkem SEQ Sexual Experience Questionnaire (Fitzgerald, Gelfand a Drasgow 1995), který je velmi často využíván v zahraničních výzkumech (Walsh, Duffy a Gallagher-Duffy 2007). Konkrétně se jednalo o otázky zjištující frekvenci zkušeností s jednotlivými druhy chování, které spadají pod definici sexuálního obtěžování. Přestože jsme SEQ nepřejali kompletně, tento postup nám nabídl orientační srovnání výskytu obtěžování v českém a zahraničním prostředí. Konkrétně bylo zjištěno, že míra obtěžování českých vysokoškolských studentek a studentů ze strany vyučujících je zhruba stejná jako v zahraničí (Lipson 2001). Použitý dotazník byl rádně pilotovaný a při zpracování získaných dat se prokázala jeho přiměřená validita a reliabilita. Nástroj z výzkumu na vysokých školách se stal východiskem pro formulování dotazníku pro středoškolské studující. Do dotazníku pro druhý výzkum byly některé položky převedeny doslovně, jiné byly použity po úpravě, část však nebyla zahrnuta vůbec, a naopak některé nové položky byly vytvořeny. Výsledky obou výzkumů tak lze v některých aspektech plně komparovat. 
Dotazník pro střední školy se skládal ze sedmi tematických bloků: 1) frekvence osobních a zprostředkovaných zkušeností týkajících se šestnácti projevů chování, které splňují charakteristiky obtěžování, ale nebyly tak explicitně označeny; 2) posouzení, zda těchto šestnáct projevů chování považují respondenti/respondentky za obtěžující; 3) otázky týkající se toho, kdo obvykle obtěžuje a kdo je obtěžován; 4) identifikace situací, v nichž obvykle k obtěžování dochází; 5) konkretizace obvyklých a optimálních reakcí studujících na obtěžování ze strany vyučujících; 6) komentování čtyř scénářů popisujících konkrétní situace, které zahrnovaly projevy, jež splňují charakteristiky obtěžování (považují je studující za obtěžování?, jaké pocity v nich vyvolávají?); 7) pět identifikačních otázek (věk, pohlaví, typ studované školy atd.). $V$ tomto článku se budeme přednostně zaměřovat na výsledky vyplývající z šestého bloku, který se týkal posuzování scénářů, přičemž je budeme kombinovat $\mathrm{s}$ výsledky druhého bloku, v němž respondenti/respondentky hodnotili, nakolik jsou jednotlivé projevy obtěžující.

Všechny položky byly uzavřené s výběrem odpovědí či polootevřené s nabídkou doplnění vlastní odpovědi; tyto byly následně okódovány. V̌̌echna data pak prošla zpracováním prostřednictvím standardních statistických procedur. Kromě třídění prvního a druhého stupně byly použity také faktorová analýza, korelační koeficienty a testování hypotéz pomocí chí-kvadrátu, Studentova t-testu a Mann-Whitney U testu.

Do šetrení bylo zahrnuto 1237 studujících z patnácti středních škol z celé České republiky. Soubor respondentů/respondentek byl sestaven reprezentativně vzhledem k současné studentské populaci podle typu střední školy (tj. gymnázia, stř̌ední odborné školy, střední odborná učiliště, odborná učiliště a učiliště). Vedlejšími znaky při sestavování souboru byly oborové zaměření a lokalita. Podle našich zkušeností je téma výzkumu pro vedení škol problematické, a proto jsme při vyhledávání konkrétních tříd nevyužívali ryze náhodný výběr, nýbrž jsme primárně vycházeli z kontaktů na školy, se kterými jsme již v minulosti spolupracovali či na ně měli reference. Zadání dotazníků probíhalo vždy v celých třídách v průběhu jedné vyučovací hodiny bez přítomnosti vyučujících. Studující byli informováni o účelu šetření, byli požádáni o souhlas s účastí a ujištěni o anonymitě šetření. Po samostatném vyplnění dotazníku byla studujícím nabídnuta možnost se zadavatelem/zadavatelkami diskutovat či je následně kontaktovat.

Výzkumný soubor se skládal z $58 \%$ dívek a $42 \%$ chlapců. ${ }^{8}$ Průměrný věk respondentů/respondentek byl 17,5 let, protože jsme se cíleně zaměřovali zejména na starší ročníky (60 \% třetí a čtvrtý ročník), které měly delší zkušenost se středoškolským studiem a zároveň jsou vyspělejší. Zahrnuli jsme však i respondenty/respondentky z prvního $(17 \%)$ a druhého ročníku (23\%), což nám umožnilo sledovat vývojový trend, pokud jde o uváděné zkušenosti.

Zadání dotazníků ve třídách prováděl výzkumný tým. Tým vedli P. Pavlík a I. Smetáčková, členkami týmu byly studentky katedry genderových studií FHS UK, jmenovitě K. Fifková, J. Sedláčková a K. Štanclová.

8 Soubor nebyl reprezentativní z hlediska pohlaví. V cílové populaci tvoří studentky-dívky $49 \%$ a studenti-chlapci $51 \%$.V rámci statistického zpracování byla provedena náhodná redukce s cílem dosáhnout reprezentativnosti z hlediska zastoupení dívek a chlapců. Výsledky plného a redukovaného souboru nebyly signifikantně rozdílné. Proto jsme se rozhodli pro další analýzy ponechat soubor celý, tj. 1237 studujících. 
Jednotlivé typy středních škol byly zastoupeny následovně: gymnázia $29 \%$, střední odborné školy $45 \%$ a učební obory $26 \%$, což v rozptylu dvou procentních bodů odpovídá složení cílové populace. Zastoupení dívek a chlapců na gymnáziích bylo rovnoměrné, na středních odborných školách převažovaly dívky a v učebních oborech naopak chlapci, což odpovídá reálnému stavu.

\section{Scénáře jako specifický nástroj sběru dat}

Scénáře nejsou v psychologických ani sociologických výzkumech často využívanou technikou. Přitom však skýtají řadu výhod. Za jejich hlavní přednost považujeme to, že respondenti/respondentky uvažují na základě scénářů o konkrétních událostech, aniž by přitom museli vycházet ze svých osobních zkušeností, vůči nimž již mají vytvořený pevný postoj. V př́ípadě extrémních jevů, jako je sexuální obtěžování, se tím snižuje riziko sekundární traumatizace, která by necitlivým připomenutím nepř́ijemného zážitku mohla nastat. Zároveň se zvyšuje validita dat, nebot' v prŕípadě mimořádného emočního rozpoložení, k němuž evokace vlastních vzpomínek často vede, může dojít ke zkreslení, respektive pod vlivem momentálního stavu k vychýlení údajů. Scénáře v tomto smyslu chápeme jako eticky méně problematický nástroj sběru dat o subjektivně náročných zkušenostech.

Za další výhodu scénářů můžeme považovat jejich méně schematický charakter. Zatímco dotazníky v rámci kvantitativně pojatých výzkumů používají spíše zobecněné, od konkrétních dílčích vlivů očištěné popisy, které vedou k deskripci jevu abstrahované od reality, scénáře představují nakročení do kvalitativní metodologie. Studovaný jev se totiž nesnaží vymanit z konkrétního situačního kontextu, nýbrž naopak prvky, které tento kontext obsahuje, využívá k interpretaci dat. Ta sice mají kvantitativní (a tedy redukující) povahu, ovšem jsou získávána prostřednictvím podnětů, které připouští, ba zdůrazňují komplexnost a dynamiku sociální reality.

Ačkoliv jsou ve výzkumech interpersonálních vztahů a konkrétně sexuálního obtěžování scénáře využívány poměrně zřídka, v některých jiných oblastech mají naopak dlouhou tradici. Výzkumná šetření využívající scénáře jsou pěstována zejména na poli vývoje společnosti jako celku, společenských segmentů či organizací. Scénáře jsou zde jednak výsledkem výzkumu (cílem je na základě získaných dat navrhnout scénář možného vývoje), jednak nástrojem sběru dat (scénáře jsou předkládány $\mathrm{k}$ posouzení respondentům/respondentkám). Přestože spolu obě role souvisí, soustřed'me se zejména na scénáře při sběru dat. S ohledem na to, jaké je zaměření použitých scénářů a jaké otázky na ně navazují, je možné běžně užívané scénáře třídit. Podle L. Börjesona (2006) můžeme rozlišovat šetření prediktivní, explorativní a normativní. Tato typologie se nám jeví užitečná i pro aplikaci na výzkumy interpersonálních vztahů. Prediktivní šetření se snaží prostřednictvím scénářů zodpovědět otázku „Co se stane?“. Dílčí otázky tedy směřují k tomu, jak by se podle respondentů/respondentek popsaná situace zřejmě dále vyvíjela, př́padně jak by se k ní oni sami stavěli. Explorativní šetření sledují otázku „Proč?“. Respondenti/respondentky mají za úkol identifikovat faktory, které byly př́ičinou nastalé situace, nebo okolnosti, za nichž může dojít ke změně. Normativní šetření používají scénáře k identifikaci určité zásady či kritéria. Scénář může tuto zásadu stvrzovat, nebo naopak porušovat, a úkolem respondentů/respondentek je ji nalézt a pojmenovat. 
Na základě charakteru doprovodných otázek můžeme shrnout, že v našem výzkumu jsme scénáře využívali zejména v prediktivním a částečně normativním smyslu.

Naše rozhodnutí zařadit scénáře do dotazníku, jehož cílem bylo zmapovat zkušenosti a postoje studujících k sexuálnímu obtěžování ze strany vyučujících, bylo inspirováno zahraničními výzkumy a odbornými diskusemi, které se vedou o metodologii výzkumů sexuálního obtěžování (například Koss a Oros 1982; Lengnick-Hall 1995; Arvey a Cavanaugh 1995; Nielsen a kol. 2010). Klíčovou otázkou je, prostřednictvím jaké metodologie a konkrétní metody sběru dat lze získat nejvíce validní a reliabilní informace o výskytu obtěžování. Jejímu zodpovězení musí předcházet vyjasnění toho, z jakého pojetí a vymezení sexuálního obtěžování výzkum bude vycházet. Jak bylo řečeno v úvodu, sexuální obtěžování lze definovat z odborných či laických pozic a ve vymezení lze akcentovat objektivní či subjektivní aspekty. ${ }^{9}$ Tomu je pak třeba podřídit výzkumný design. Tradiční standardizované dotazníky SEQ (Fitzgerald a kol. 1995) a SES (Koss a Oros 1982) vychází z odborných definic, a tedy zjišt'ují, zda se respondenti/respondentky setkali s jednotlivými projevy chování, které podle externí definice náleží pod označení sexuální obtěžování (aniž by tento pojem byl v dotazníku použit). Jiným př́istupem, který vede ke zjištění tzv. laické či aktérské definice, je dotazování na to, jak respondenti pojmu sexuální obtěžování rozumí a zda se s ním setkali. Oba postupy vedou k vysoce rozdílným údajům o prevalenci obtěžování, přičemž v druhém případě je výskyt zkušeností výrazně nižší. Výzkumy obvykle využívají jeden ze zmíněných postupů, ovšem je možné je i zkombinovat. ${ }^{10}$

Právě k jejich kombinaci jsme přistoupili i v našem výzkumu. Výsledný dotazník tedy obsahoval dvě základní části, z nichž první uplatňovala odbornou definici a druhá definici aktérskou. První baterie mapovala prostřednictvím tříbodové škály (nikdy - občas - často) frekvenci ${ }^{11}$ zkušeností s šestnácti projevy chování, které vycházely z dotazníku SEQ. ${ }^{12}$ Druhá baterie zjišt'ovala prostřednictvím čtyřbodové škály (ano - spíše ano - spíše ne - ne), zda

9 Různým způsobům definování sexuálního obtěžování jsme se věnovali v jiném textu (Smetáčková a Pavlík 2011).

10 Kombinace ovšem vždy předpokládá, že jeden z dílčích postupů je použit jako první, čímž může být výsledek ovlivněn. Dotazník začíná bud' výčtem chování, po němž následuje vymezení pojmu a vyjádření vlastní zkušenosti s pojmenovaným fenoménem, nebo naopak začíná osobní definicí pojmu, po níž následuje zjišt'ování výskytu chování.

11 Frekvence zkušeností byla zjišt'ována pouze pomocí takto hrubé škály, nebot' se na základě pilotáže ukázalo, že jemnější členění není pro respondenty/respondentky přehledné a nedokáží v něm podávat spolehlivé odpovědi. Nevýhodou použité škály je její neurčitost, což však není zásadní nedostatek vzhledem k cíli výzkumu, jímž bylo zmapovat subjektivní přistup studujících. Při interpretacích je třeba pamatovat na to, že pod označením „občas“ či „často“ se může skrývat pro různé osoby odlišný časový údaj.

12 Baterie byla uvozena následující formulací: Setkal/a jste se během studia na středni škole s následujicim chováním ze strany svých učiteli a učitelek? U každého chování označte, zda chování bylo namíreno na Vás osobně nebo jste jej zažil/a ve Vaši třídě nebo jste se o něm pouze doslechl/a. Posuzováno bylo šestnáct druhů chování, a to vždy ze tří hledisek: 1) toto chování jsem zažil/a já osobně, 2) s tímto chováním jsem se setkal/a v naši tř́dě, 3) od ostatních vím o tomto chování viných třidách či školách. 
těchto šestnáct projevů vnímají studující jako obtěžování, tj. jaké chování spadá do jejich vlastní definice obtěžování. Posuzované typy chování byly: 1) odlišný př́stup (chování, hodnocení) $\mathrm{k}$ určitému člověku v porovnání s přístupem $\mathrm{k}$ ostatním lidem ve třídě; 2) zesměšňující až urážlivé poznámky na konkrétního člověka; 3 ) nepatřičné komentování těla či vzhledu konkrétních lidí; 4) dotyky a vstupování do osobního prostoru (například ruka kolem ramen); 5) projevování osobního zájmu, který přesahuje rámec školy a obvyklý vztah k ostatním studujícím; 6) vážně míněné poznámky o odlišnosti žen a mužů, které snižují jednu z těchto skupin (např́klad ženy nerozumí počítačům tak dobře jako muži); 7) humorné poznámky či vtipy na ženy a muže a jejich odlišné charakteristiky (napríklad muži a ženy jsou dva různé živočišné druhy, vtipy o blondýnách); 8) neobvykle intimní pohledy (např́klad pohledy do výstřihu); 9) sexuálně podbarvená gesta, pohyby či výrazy obličeje; 10) ukazování materiálů se sexuálním obsahem nesouvisící s výukou; 11) rozhovor či vyprávění vtipů a př́běhů týkající se sexu bez souvislosti s výukou; 12) intimnější dotyky (například poplácání po zadku, pohlazení po tváři); 13) pozvání na osobní schůzku či rande mimo školu; 14) naznačování či př́mo nabízení výhod za intimní sblížení; 15) pohrǔžka trestů či nevýhod při odmítnutí intimního sblížení; 16) použití fyzického násilí pro vynucení sexu.

Další částí dotazníku pak byly scénáře, které tvořily jisté přemostění a zároveň nástroj zpřesňování i validizace dat. $\mathrm{V}$ dotazníku pro středoškoláky/středoškolačky byly zadány čtyři scénáře, které jsou popsány níže. Každý scénář byl formulován tak, aby dovoloval dosadit si za aktéry ženy i muže, a dále aby obsahoval dostatek podrobností pro představu o situaci, ale současně ne tolik, aby to činilo jejich interpretace zcela shodné. Naším cílem bylo popsat situaci tak, jak by se jevila v první fázi pozorování, před tím, než pozorovatelé/pozorovatelky začnou o chování aktérů uvažovat. Na ni v rámci procesu sociální percepce a kognice nutně navazuje fáze systematické interpretace. Ta byla stimulována pomocí doprovodných otázek. Studující byli požádáni o posouzení jednotlivých situací z hlediska pocitů, které by v nich mohly vyvolávat, a dále o vyjádření, nakolik je popsané chování podle nich obtěžováním. Scénáře umožňují, aby se respondenti/respondentky na základě toho, jak blízká je pro ně popsaná událost, identifikovali s určitou postavou, nebo zaujali vnější pozici svědka. Aktivizace posuzovatelské pozice může být bud' pouze zjištována, nebo s ní dokonce může být aktivně manipulováno.

Vyjádření ke scénářům jsou zajímavá jednak sama o sobě, ale dále také v kombinaci s odpověd'mi na ostatní položky v dotazníku, konkrétně na vymezení sexuálního obtěžování. Porovnání přináší zjištění o tom, jak studující vnímají a prožívají hranice ve vztazích mezi vyučujícími a studujícími, z čehož lze eventuálně vyvodit i praktická doporučení. Scénáře i některé další položky byly zadány ve výzkumu středních škol i vysokých škol, a proto lze navíc jejich výsledky porovnat, čímž dojde $\mathrm{k}$ rozšíření závěrů o aspekt věku a povahy vzdělávacích institucí.

\section{Základní výsledky: výskył a definice}

Dřive než přejdeme k hodnocení scénářŭ, je nutné ve stručnosti představit hlavní výsledky dalších částí dotazníku. Věnovat se budeme zejména prvním dvěma bateriím položek, které zjištovaly výskyt zkušeností $s$ jednotlivými projevy a jejich přiřazení $\mathrm{k}$ pojmu obtěžování. Jak již bylo zmíněno, studující posuzovali šestnáct typů chování, které spadají pod odbornou definici 
genderově motivovaného a sexuálního obtěžování v tradici L. Fitzgerald (1995). S některým $\mathrm{z}$ těchto projevů se setkaly až dvě třetiny studujících. Frekvence zkušeností variuje od odpovědi „občas“ po odpověd” „často“, přičemž občasných zkušeností je až 4x více než častých zkušeností. Oba údaje jsme se však rozhodli spojit, nebot' v obou případech studující musí čelit porušování hranic pedagogického vztahu, i když samozřejmě platí, že časté porušování je identitně i interpersonálně problematičtější. Údaje o frekvenci navíc nelze přesně stanovit, protože náš výzkum se zaměřoval nikoliv na získání kvantitativně přesných údajů o výskytu, nýbrž na zmapování studentské subjektivní perspektivy vůči fenoménu obtěžování, tj. na to, jaký význam studující dávají událostem, s nimiž se setkávají, a tedy jaké postoje si na jejich základě budují, což má následně klíčový vliv na jejich prožívání a chování.

Jak ukazuje Graf 1, míra zkušenosti s jednotlivými projevy se značně liší, a to jak v údajích za celý soubor, tak i v porovnání odpovědí dívek a chlapců. Nejvíce zkušeností mají studující $\mathrm{s}$ uplatňováním odlišného chování v porovnání $\mathrm{s}$ dalšími lidmi ve tř́dě a s využíváním humoru, který danou osobu zesměšňuje či př́padně uráží. Naopak zkušenosti s chováním, které má explicitně sexuální obsah, a navíc uplatňuje vydírání, jsou relativně rídké. ${ }^{13}$ Obdobný poměr výskytu zkušeností s jednotlivými typy projevů se ukazuje také v zahraničních výzkumech, tj. formy chování, v nichž se jedná o explicitní a jednoznačné zneužití moci ze strany vyučujících a absolutní sexualizaci pedagogického vztahu, jsou méně časté. Důvodem je relativně vysoká společenská shoda, že takové chování se neslučuje s pedagogickým vztahem, což znamená hlubší sociální kontrolu i sebekontrolu aktérů, at' již neformální, či formalizovanou v podobě etických kodexů.

Naopak překvapivě odlišným výsledkem v porovnání se zahraničními výzkumy (například AAUW 2001; Winters, Clift a Maloney 2004) je vyšší výskyt chlapeckých zkušeností s většinou posuzovaných projevů. S některým z projevů se setkalo $69 \%$ chlapců, ale ,jen“ $61 \%$ dívek, což je statisticky významný rozdíl. Vysvětlení odlišnosti mezi českými a zahraničními výsledky může spočívat bud' ve znění dotazníku, nebo v hloubce a povaze povědomí o genderovém rrádu, které panuje $\mathrm{v}$ české společnosti. $\mathrm{V}$ př́padě druhého vysvětlení, $\mathrm{k}$ němuž se přikláníme, by to znamenalo, že dívky méně registrují posuzované chování, protože se s ním setkávají natolik často, že jsou na něj zvyklé a že jej dokonce očekávají jako potvrzení jejich feminity. Je tedy možné, že chování překračující genderové a sexuální hranice je fakticky produkováno častěji vůči dívkám, ovšem ty jej považují za natolik samožrejmé, že je to vede $\mathrm{k}$ jeho přehlížení. Jestliže tomuto chování dívky nepřikládají význam, zkušenosti s ním si ani neuvědomují a nemohou je v dotazníku reflektovat.

Stejná logika by pak znamenala, že chlapci jsou v aktuálním genderovém kontextu, který očekává u maskulinity sexuální expanzivitu, podporováni $\mathrm{v}$ tom, aby podobné chování produkovali, čímž se stávají vůči němu všímavější a také angažovanější ve smyslu, že se na něm sami podílí. Skutečnost, že chlapci uváděli v dotazníku více zkušeností s daným chováním než dívky, tedy může vyplývat ze dvou odlišných faktorů (samozřejmost chování pro dívky a vlastní produkce chování chlapci), které se vzájemně synergicky doplňují. Tato

13 Ačkoliv zkušenosti s některým z těchto projevů uvádí pouze dvě procenta studujících, nejedná se o zanedbatelný počet. Vyjdeme-li ze současného počtu studujících na středních školách (Statistická ročenka školství 2011), pak by tento podíl představoval téměř 10000 dívek a chlapců. 
hypotéza platí zvláště u druhé a třetí skupiny projevů, tj. uživání genderových stereotypů a sexuální pozornosti. Chlapci dané projevy registrují, avšak zřejmě ne z pozice objektu, vůči němuž je dané chování namířeno. Například užívání gest se sexuálním podtextem či prezentace materiálů se sexuálním obsahem může ze strany vyučujících vůči chlapcům směřovat jako vůči „part’ákům“. V rámci školního prostoru se tak vytváří jakési maskulinní společenství zahrnující učitele-muže a studenty-chlapce. ${ }^{14}$

\section{Graf 1: Osobní zkušenosti s učitelskými projevy (občas + často), N = 1237}

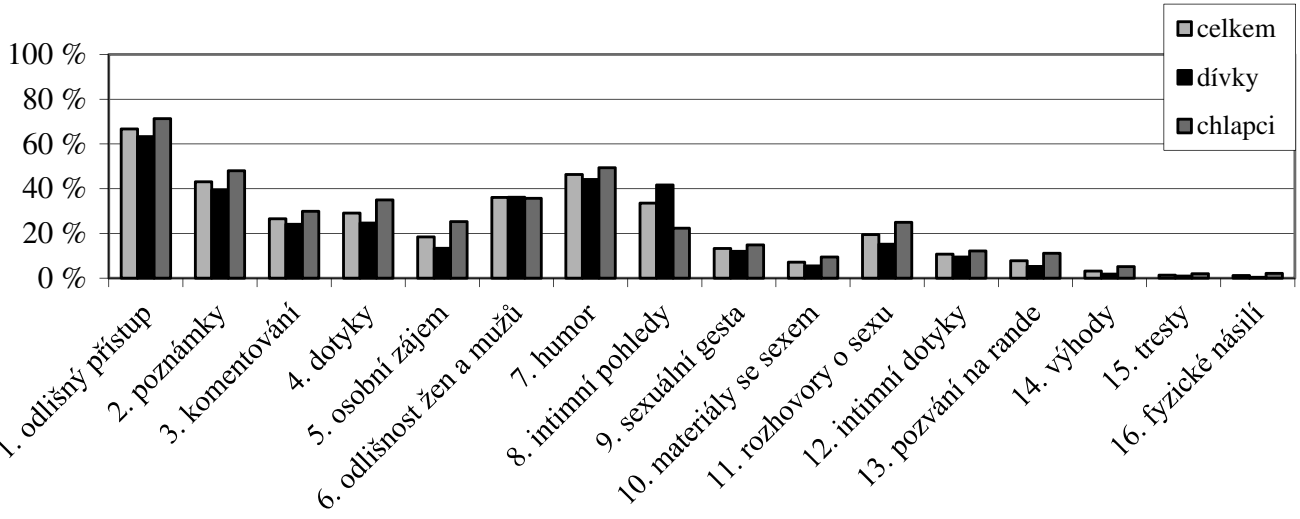

Pokud odpovědi podrobíme obsahovému a statistickému rozboru, ${ }^{15}$ vznikne typologie, která vychází z výše zmíněné odborné definice obtěžování a zároveň ji doplňuje. V této typologii budeme rozlišovat následující čtyři skupiny projevů: nespravedlivé zacházení, uživání genderových stereotypů, sexuální pozornost a sexuální nátlak.

Nespravedlivé zacházení (dotazníkové položky 1-5) představuje chování bez primární př́tomnosti genderového či sexuálního rozměru, při němž vůči konkrétní osobě nejsou uplatňována pravidla platná pro ostatní. Tím dochází $\mathrm{k}$ vyčlenění daného člověka ze studentského kolektivu, v němž by si měli být ve vztahu k vyučujícím všichni rovni (Freiberg 1999).

Užívání genderových stereotypů (dotazníkové položky 6 a 7) obsahuje širokou škálu projevů, jejichž společným jmenovatelem jsou zevšeobecňující představy o tom, jakými schopnostmi a vlastnostmi disponují ženy a jakými muži. Východiskem je přitom polarizace a dichotomizace maskulinity a feminity, které mohou vyústit až v diskurz „boje pohlavi““ (Bourdieu 2000). Na základě aplikace těchto představ pak může dojít ke znevýhodnění konkrétních dívek a chlapců, kteří se dominantním genderovým představám vymykají (Sadker,

14 Zároveň se může část reflektovaných zkušeností týkat poznámek, které zpochybňují maskulinitu chlapců, naprríklad ve sportu. Také je nutné zvážit jako vysvětlení, že část chlapců nebrala dotazník vážně a nadhodnocovala své zkušenosti. U chlapců v pubertě by to nebylo nic překvapivého.

15 Při rozboru jsme aplikovali dvě hlediska - jednak vnější podobnost projevů (bez ohledu na získaná data), jednak pravidelnost žákovských odpovědí, která je odhalitelná zejména pomocí faktorové analýzy. 
Sadker a Zittleman 2009). Prezentace genderových stereotypů variuje od vážně míněných komentářů přes urážlivé a zesměšňující poznámky až po humor.

Sexuální pozorností (dotazníkové položky 8-13) se míní projevování zájmu o konkrétní osobu či skupinu osob, který má erotický podtext, nebo nepatřičné zaměřování pozornosti $\mathrm{k}$ sexuálním tématům.

Sexuální nátlak (dotazníkové položky 14-16) zahrnuje vybízení k sexuálním praktikám různého druhu, které jsou vyváženy získáním výhody či naopak potrestáním při nevyhovění. Vyučující přitom využívají (zneužívají) svoji institucionální i neformální převahu nad studujícími.

Pokud porovnáme výskyt zkušeností s uvedenými čtyřmi skupinami chování, pak se zřetelně ukazuje, že frekvence se mění s ohledem na explicitnost sexuálních obsahů. Výsledky ukazuje Tabulka 1. Nejméně zkušeností mají studující se sexuálním nátlakem, více s uplatňováním sexuální pozornosti a nejvíce s využíváním genderových stereotypů. Rozdíl mezi těmito druhy chování spočívá také $\mathrm{v}$ tom, jak ohrožující z hlediska tělesné a psychické integrity dané chování obvykle bývá. Sexuální nátlak je v tomto ohledu nejzávažnější, zatímco uplatňování genderových stereotypů má neprímý a spíše dlouhodobý efekt, a není proto jedinci prožíán tak úkorně.

Tabulka 1: Zkušenosti se skupinami projevů, N SŠ = 1237, N VŠ = 832

\begin{tabular}{|c|c|c|}
\hline & SŠ & vš \\
\hline Sexuální nátlak & $2 \%$ & $6 \%$ \\
\hline Sexuální pozornost & $15 \%$ & $22 \%$ \\
\hline Genderové stereotypy & $41 \%$ & $62 \%$ \\
\hline Nespravedlivé zacházení & $37 \%$ & $48 \%$ \\
\hline
\end{tabular}

Protože v dotazníku pro vysoké školy byly zahrnuty obdobné projevy chování, můžeme provést jejich porovnání. Jak vyplývá z Tabulky 1, zkušenosti vysokoškolákủ/vysokoškolaček s jednotlivými skupinami chování jsou vyšší (rozdíl je statisticky významný na hladině $1 \%$ ). Na vzniku rozdílu se podle nás podílí dva faktory. Jedním je vyšší zralost a z ní vyplývající hlubší sebereflexe i sebejistota studujících na vysokých školách, které jim umožňují, aby si snadněji uvědomili nevhodnost učitelského chování a eventuálně se mu i postavili. Druhým faktorem je menší časoprostorová i kurikulární rigidita výuky na vysokých školách, která ústí ve volnější pedagogické vztahy, v nichž více hrozí překračování hranic. ${ }^{16}$ Vyšší

16 Dotazník pro střední školy ověřoval výskyt obtěžování v různých typech situací kombinujících míru formální regulace, množství aktérů a konkrétní prostředí. Podle studujících dochází k obtěžování nejčastěji během školních akcí mimo školu, konzultací/doučování a volnočasových aktivit ve škole, kdy v situaci neplatí zřetelná pravidla jako ve výuce. To znamená, že prostor školy není sám o sobě garancí toho, že bude dodržován profesionální odstup mezi vyučujícími a studujícími. Významnějším faktorem je míra strukturace času a aktivit. Čím menší tato strukturace je, tím volnější pravidla $\mathrm{v}$ situaci panují a tím snadněji může dojít $\mathrm{k}$ jejich překročení. $\mathrm{V}$ těchto situacích 
míra zkušeností s obtěžováním na vysokých školách tedy zřejmě vyplývá z hlubší schopnosti vysokoškolských studujících si takové chování uvědomit a zároveň i z reálně většího výskytu takového chování.

Ve výzkumu středních škol jsme se kromě osobních zkušeností s obtěžováním zaměřovali také na mapování zkušeností zprostředkovaných, tj. na obtěžování vyskytující se ve vlastní trrídě, kterého byli respondenti/respondentky svědkem, a dále na obtěžování na jiných školách, které znají z doslechu. Jak jsme předpokládali i na základě zahraničních nálezů (Walsh, Duffy a Gallagher-Duffy 2007), výskyt zprostředkovaných zkušeností byl vyšší než výskyt zkušeností osobních. At' už je vyšší podíl zprostředkovaných zkušeností důsledkem fabulace a zveličování informací z doslechu, nebo snahy zabránit identitnímu ohrožení bagatelizací a snížením počtu osobních zkušeností, výsledky poukazují na to, jak studující vnímají klima ve vzdělávacím systému a jaká mají očekávání vůči vztahům mezi vyučujícími a studujícími. Pokud považují obtěžující chování za časté, roste pravděpodobně jejich tendence hodnotit jej jako přijatelné.

To naznačují i výsledky z druhé části dotazníku, ve které studující hodnotili, nakolik podle nich mají jednotlivé projevy chování obtěžující potenciál. Studující to posuzovali na škále od 1 do 4 , přičemž 1 představuje nejvíce obtěžující a 4 nejméně obtěžující chování. Pro přehlednost užíváme namísto procentuálního podílu odpovědí index, který vyjadřuje průměr studentského hodnocení na škále. Do jaké míry je chování pro studenty/studentky obtěžující, ukazuje Graf 2. Za nejvíce obtěžující je pokládán sexuální nátlak, tj. projevy 14-16. Průměrný index skupiny je 1,7. První a třetí skupina projevů, tj. nespravedlivé zacházení a sexuální pozornost, shodně dosáhly indexu 2,1 . Hodnocení projevů ve třetí skupině má relativně velký rozptyl. ${ }^{17}$ Zatímco rozhovory se sexuální tematikou studující vnímají jako spíše neobtěžující, fyzický kontakt je pro ně ohrožující. Podobně (avšak v menší míře) se v první skupině vymykají zesměšňující či urážlivé poznámky. Za nejméně obtěžující je považováno používání genderových stereotypů (hodnota indexu je 2,7), a to jak ve formě humoru, tak i vážně míněných poznámek o rozdílech mezi ženami a muži. ${ }^{18}$

Jak rovněž ukazuje graf, dívky hodnotí jednotlivé projevy jako více obtěžující než chlapci (rozdíl je statisticky signifikantní na hladině významnosti $1 \%$ ). Nejsilnější jsou rozdíly u sexuální pozornosti (tj. intimní pohledy, sexuální gesta, materiály se sexem a rozhovory o sexu), kde průměrný index dívek činil 1,92 a chlapců 2,43 . Větší kritičnost dívek vůči

může být formální řád školy nahrazen řádem genderovým, v rámci něhož se vztahy vyučujících a studujících stávají potenciálně sexualizované.

17 Na základě tohoto výsledku, který koresponduje i s výzkumem na vysokých školách, navrhujeme uvažovat o úpravě typologie genderově motivovaného a sexuálního obtěžování inspirované L. Fitzgerald (1995). Kategorie „sexuální pozornost“ by měla být rozčleněna na dvě nové kategorie, které pracovně označujeme „osobní sexuální pozornost“ a „pozornost vůči sexuálním tématům“. Diskusi této změny typologie věnujeme jiný text.

18 Poměrně časté je obohacování výuky o vtipy týkající se žen a mužů či rozdílů mezi nimi, např́íklad učitel komentuje chování konkrétní dívky: „No jo, Hanka se zase projevila jako typická blondýna, přesně jako v tom vtipu... “ Mnohdy jsou však učitelské komentáře týkající se nedostatkủ žen či mužů míněny vážně. Například velmi často studentky uváděly, že se setkávají se snižováním ženských schopností, zvláště v určitých předmětech či oblastech: „, Já vím, že fyzika je prostě pro dívky moc náročná a že od vás nemůžu čekat, že ji opravdu pochopíte. “ 
učitelskému chování dokládají i zahraniční výzkumy (Chrisler a McCreary 2010; Lipson 2001). Ty docházejí $\mathrm{k}$ tomu, že dívky považují nepatřičné učitelské chování za více ubližující než chlapci, a zároveň, že jsou vystaveny závažnějším formám obtěžování. Z hlediska subjektivních pocitů, které učitelské chování vyvolává u dívek a chlapců, se tedy čeští dospívající neliší od zahraničních (Timmerman 2003; Lipson 2001 aj.). Ovšem o to překvapivější je opačný výsledek týkající se zkušeností dívek a chlapců s posuzovaným chováním.

Graf 2: Míra obtěžování ( 1 - nejvíce, 4 - nejméně), N = 1237

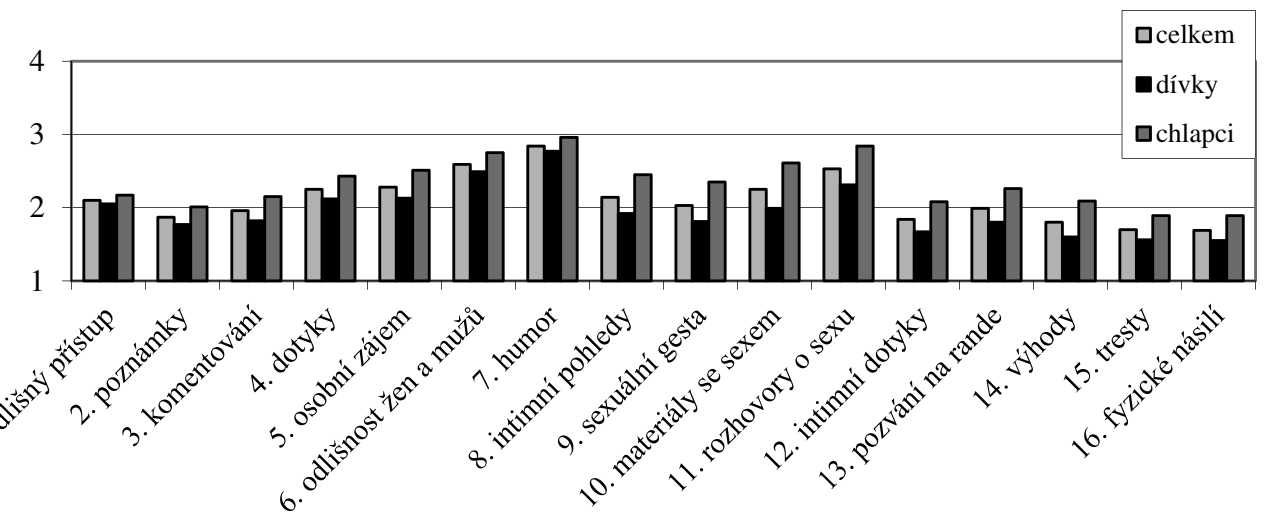

V datech se prokázala statisticky významná souvislost mezi osobní zkušeností a nepříjemnými pocity, a to $\mathrm{v}$ př́ípadě až poloviny projevů (neplatí pro projevy $8,10-16$ ), přičemž výrazně silnější je $\mathrm{v}$ př́ípadě dívčích odpovědí. $\mathrm{V}$ podsouboru dívek jsme identifikovali dvě skupiny, z nichž jedna posuzované projevy nehodnotí jako obtěžující a zároveň s nimi nemá zkušenosti a druhá zkušenosti má a projevy označuje za obtěžující. $Z$ toho vyplývá, že v př́padě dívek zkušenosti s obtěžujícím chováním mohou vést $\mathrm{k}$ jeho kritičtějšímu posuzování, nebo naopak, že vnímaná nepř́ijemnost chování způsobuje zcitlivění vủči zkušenostem. V souladu s hypotézou vysvětlující vyšší výskyt zkušeností s obtěžováním mezi chlapci se přikláníme $\mathrm{k}$ tomu, že kauzalita mezi oběma proměnnými má následující směr: vznik nepříjemných pocitů (pokud $\mathrm{k}$ němu dojde) způsobuje vyšší senzitivizaci a reflexi obtěžujícího chování. Pro potvrzení tohoto vztahu bude nutné realizovat specifické výzkumné šetření.

\section{Scénáře: pocity a hranice}

Nyní přejdeme $\mathrm{k}$ prezentaci výsledků týkajících se scénářů. Jak bylo řečeno výše, do dotazníku pro střední školy byly zařazeny čtyři scénáře, které se vztahovaly k různým typům obtěžování: Scénář A - sexuální nátlak: Studentovi/ce hrozí propadnutí. Učitel/ka významně ríká: ,Vaše výsledky jsou tak špatné, že mi nezbývá, než vám dát na vysvědčení za pět. Možná bychom to ale mohli ještě nějak zvrátit. Záleži na tom, co všechno jste ochotnýlá pro to udělat. Pokud chcete dostat lepši známku, přijd'te večer ke mně domü. "Scénář B - sexuální pozornost: Učitel/ka opakovaně dělá nepatřičné poznámky na vzhled a osobni život studentek/ů. Např́klad když si student/ka sundává při hodině mikinu, významně se na něj/ 
ní dívá a přitom řiká: „Klidně s tím svlékáním pokračujte. To mě zajímá, co přijde dál." Scénář C - mimořádný osobní zájem: Učitel/ka dává najevo svůj osobní zájem o jednoho konkrétniho člověka ve tř́dě. Dělá poznámky na to, jak dobře vypadá, jak je inteligentní, hodně se s nílm baví o prestávkách, ptá se ho/jí na osobní život, začíná jí/mu psát osobněji laděné e-maily. Scénáŕ $\mathrm{D}$ - uplatňování genderových stereotypů: Učitel/ka komentuje vysvědčení: „, Mezi děvčaty není žádná s jedničkou z matematiky nebo fyziky. Opět se nám potvrdilo, že holky nemají na tyhle předměty prostě buňky. Ale u kluků bychom takovou oblast taky našli, např́klad starat se o děti jim dělá od přirody potiže. “

Každý scénáŕ byl doprovozen následující sadou otázek: 1) Jak byste se Vy osobně cítil/a v pozici studenta/ky? 2) Jak byste se cítil/a, kdybyste byl/a svědkem podobné situace? 3) Je podle Vás popsané chování v souvislosti se školou v pořádku? 4) Je podle Vás takové chování obtěžováním? První dvě otázky byly zodpovídány na pětibodové škále dobře-špatně, třetí a čtvrtá otázka na pětibodové škále ano-ne. V následující Tabulce 2 prezentujeme souhrnné výsledky $\mathrm{k}$ jednotlivým scénářům. Pro vy̌̌ší př̌ehlednost používáme průměrné údaje namísto procentuálního zastoupení odpovědí.

Tabulka 2: Hodnocení scénářơ, N = 1237

\begin{tabular}{|l|c|c|c|c|}
\hline & Osobní pocity & $\begin{array}{c}\text { Svědecké } \\
\text { pocity }\end{array}$ & $\begin{array}{c}\text { Vhodné } \\
\text { chování }\end{array}$ & Obtěžování \\
\hline Scénář A: sexuální nátlak & 4.3 & 4.06 & 4.7 & 1.72 \\
\hline Scénár̆ B: sexuální pozornost & 4.17 & 3.71 & 4.5 & 2.1 \\
\hline Scénár̆ C: osobní zájem & 3.8 & 3.7 & 4.31 & 2.33 \\
\hline Scénář D: genderové stereotypy & 3.27 & 3.16 & 3.51 & 3.43 \\
\hline
\end{tabular}

Z tabulky vyplývá, že tři posuzované situace vyvolávají ve studujících nepříjemné pocity a čtvrtý pocity spíše neutrální. Nejhorší pocity ve studujících vyvolává situace týkající se sexuálního vydírání a komentářu se sexuálním podtextem. Mírnější hodnocení přichází v př́ipadě, že studující danou situaci pouze sledují (namísto toho, aby chování směřovalo přímo vůči nim). I v prrípadě svědectví však jsou pocity spíše negativní či neutrální. Na základě toho můžeme považovat obtěžování za fenomén s četnými individuálními i skupinovými následky. Rovněž zahraniční výzkumy ukazují, že ti, kteří jsou přímými obět’mi obtěžování, musí čelit momentálním i dlouhodobým záporným důsledkům v podobě sníženého prospěchu, změn studijní dráhy, vzniku somatických problémů, poklesu celkového sebevědomí a sebeúcty atd. (Lipson 2001). Ovšem, jak se ukazuje, i pro ty, kteří obtěžování „pouze“ přihlíží, se jedná o chování ohrožující. Jaké mohou být konkrétní negativní dopady, není dostatečně výzkumně prověřeno. Domníváme se však, že tím hlavním je snížení koheze ve vrstevnické skupině, která přestává poskytovat emoční podporu a není nadále bezpečným prostředím pro kognitivní učení, jehož efektivita se tím snižuje. ${ }^{19}$

19 Studující obtěžování spojují především se vztahem mezi učiteli-muži, kteří jsou iniciátory, a studentkami-dívkami, které jsou obět’mi. To odpovídá povaze genderového řádu, v němž maskulinita 
Všechny popisované situace podle studujících překračují hranice pedagogického vztahu, tj. podobné chování by se nemělo ve škole vyskytovat. Studující opět nejmírněji hodnotí čtvrtý scénář, který se vztahuje k uplatňování genderových stereotypů. I ten však studující vidí ve školním kontextu jako spíše nevhodný. Až na genderové stereotypy považují studující všechny tři popisované typy chování za obtěžování.

Hodnocení scénářů koresponduje s výsledky v položkách, kde se studující vyjadřovali o tom, nakolik jsou konkrétní projevy chování podle nich obtěžující. I tam byl za nejvíce obtěžující považován sexuální nátlak, dále sexuální pozornost a nejméně užívání genderových stereotypů. Zdá se tedy, že v laické neboli aktérské definici genderově motivovaného a sexuálního obtěžování studující operují s dimenzí závažnosti, která vyplývá z explicitnosti sexuálního obsahu a $\mathrm{z}$ hloubky ohrožení osobní integrity. Scénáře však ukazují ještě další aspekt. Pomocí korelační a faktorové analýzy se potvrdilo, že největší blízkost existuje mezi scénáŕi $\mathrm{B}$ a $\mathrm{C}$, tj. sexuální pozornost a mimořádný osobní zájem. Tyto dvě situace, na rozdíl od zbývajících, mají následujícího společného jmenovatele - vedou $\mathrm{k}$ vyčlenění studentky či studenta z kolektivu. $Z$ toho můžeme vyvodit, že další dimenzí v laické/aktérské definici představuje polarita individuum - kolektiv, která se realizuje v kontextu instituce školy. Škola zakládá mocenskou asymetrii mezi vyučujícími a studujícími, v níž dodržování pravidel a unifikace studentské sociální role funguje jako překážka zneužívání učitelské moci. Účel školy je spojen s učením coby sociálním (tj. skupinovým) procesem, jenž ke svému zdárnému průběhu vyžaduje funkční skupinu. Pokud tedy dojde $\mathrm{k}$ př́lišné individualizaci pedagogické péče, může to vést ke znejistění obecných mechanismů školního vzdělávání.

Při posuzování scénár̊u se odpovědi dívek a chlapců lišily podobně jako v posuzování míry obtěžujícího potenciálu jednotlivých projevů. Dívky v porovnání s chlapci deklarovaly negativnější pocity, které by $\mathrm{v}$ nich daná situace vyvolala, a to at' by byly obětí, nebo svědkyní. Dívky rovněž dané chování považovaly za nevhodnější v prostředí školy a častěji ho vnímaly jako součást obtěžování. Rozdíly mezi dívkami a chlapci v hodnocení scénářu $\mathrm{A}$ až C byly statisticky významné na hladině $1 \%$, v případě scénáře $\mathrm{D}$ se signifikantní rozdíl neprokázal. Odpovědi na čtvrtou otázku (Je podle Vás takové chování obtěžováním?) shrnuje Tabulka 3 . Z ní je patrné, jak silné rozdíly v míře kritických postojů dívek a chlapců existují chlapci popisované chování hodnotili benevolentněji než dívky.

je konstruována jako dominantní a sexuálně náruživější, zatímco feminita jako submisivní, avšak současně erotizovaná (Bourdieu 2000). Genderový řád navíc předpokládá komplementaritu feminity a maskulinity, která je posilována požadavkem realizovaného či hypotetického heterosexuálního partnerského vztahu, a to a priori při téměř všech typech kontaktů mezi ženami a muži. Ačkoliv škola postuluje svoji genderovou neutralitu (tj. v rámci vzdělávacího prostředí hypoteticky ustupuje genderová př́islušnost do pozadí), ve skutečnosti je v ní genderový rád rovněž přítomen a prostřednictvím školní socializace je nereflektovaně reprodukován (Sadker, Sadker a Zittleman 2009). 
Tabulka 3: Obtěžující potenciál scénářư, N = 1237

\begin{tabular}{|l|c|c|c|c|}
\hline & A: sexuální nátlak & $\begin{array}{c}\text { B: sexuální } \\
\text { pozornost }\end{array}$ & C: osobní zájem & $\begin{array}{c}\text { D: genderové } \\
\text { stereotypy }\end{array}$ \\
\hline Dívky & 1.5 & 1.91 & 2.11 & 3.4 \\
\hline Chlapci & 2.02 & 2.37 & 2.64 & 3.46 \\
\hline Celkem & 1.72 & 2.1 & 2.33 & 3.43 \\
\hline
\end{tabular}

Dalším krokem naší analýzy bylo porovnání odpovědí vážících se na scénáře a na abstraktní popis chování. Každé chování, které se vyskytovalo ve scénáŕích, mělo svoji verzi mezi šestnácti projevy hodnocenými v úvodních bateriích. Zajímalo nás tedy, nakolik se hodnocení obtěžujícího potenciálu chování ze scénářů a z př́slušných projevů uvedených v dotazníku shoduje. Výsledky ukazuje Graf 3. Z něho je patrné, že dívky hodnotily přísněji všechny scénáře i všechny projevy hodnocené v druhém bloku dotazníku (jedinou výjimku tvoří scénáŕ D). Zároveň se ale také ukazuje, že dívky i chlapci hodnotili scénáře benevolentněji než abstrahované chování. Této pravidelnosti se ovšem opět vymyká poslední hodnocené chování, tj. užívání genderových stereotypů.

Graf 3: Posuzování scénářů a projevư chování dívkami a chlapci, N = 1237

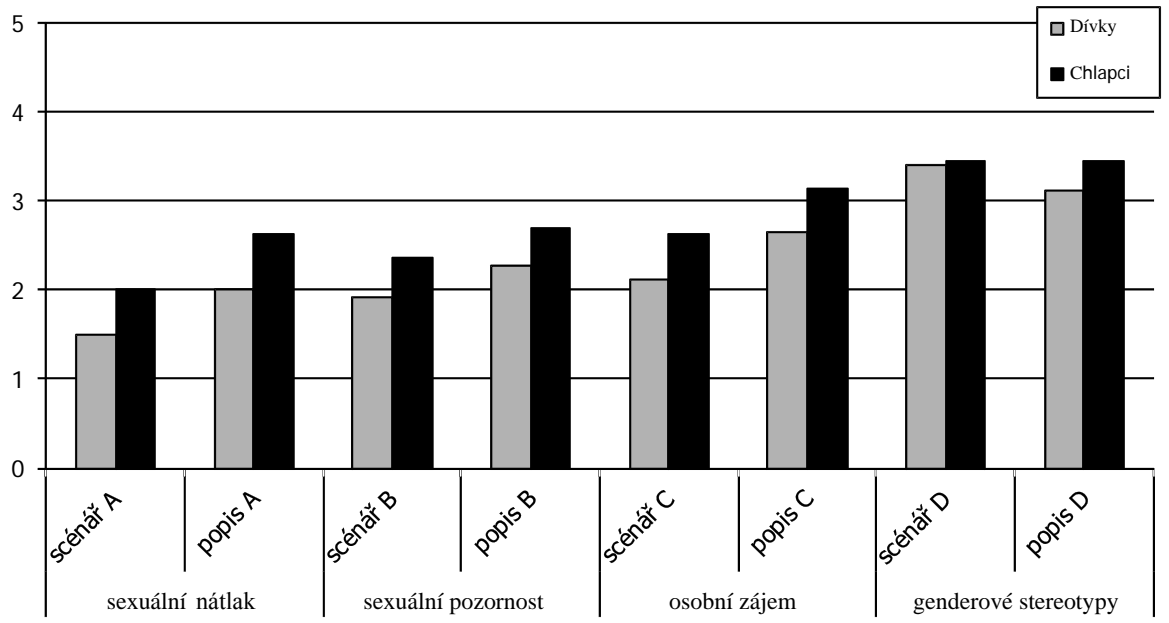

Obdobný výsledek se ukázal i ve výzkumu vysokých škol. Nejvíce studujících považovalo za obtěžování situaci, která obsahovala sexuální vydírání (93\%), nejméně situaci, v níž vyučující komentuje školní výkony konkrétního studenta/studentky a vztahuje je k představě rozdílných schopností žen a mužů, konkrétně nižšího nadání žen pro matematiku (56 \%). I v tomto př́padě však byl podíl těch, kteří dané chování hodnotili jako obtěžování, a tedy odmítali jeho výskyt v rámci vzdělávání, relativně vysoký. Mezi středoškoláky/ 
středoškolačkami se v otázce, zda je dané chování obtěžováním, přihlásilo k odpovědi „,ano“ či „spíše ano“ statisticky významně méně osob. V př́ípadě situace sexuálního vydírání to bylo $79 \%$ respondentů/respondentek, v prípadě genderově stereotypních komentáŕů $24 \%$.

Opět se tedy potvrdilo, že komentáře uplatňující genderově stereotypní očekávání na ženy a muže představují pro studující zvláštní typ chování, které nenáleží do jejich definice obtěžování. Přitom se ale jedná o chování, které v nich vzbuzuje spíše negativní pocity a které vnímají v kontextu školy jako spíše nepatřičné. Zároveň se jedná o projevy, se kterými mají četné zkušenosti. To znamená, že studující operují s výrazně užším vymezením sexuálního obtěžování, než jaké existuje v rámci odborných definic. Pod pojmem sexuální obtěžování chápou primárně ataky, které bezprostředně souvisejí se sexualitou. Ty mohou mít jak fyzickou, tak i psychickou a verbální podobu. $\mathrm{V}$ př́ípadě středoškoláků/středoškolaček jsou do laické definice zahrnuty obě formy, zatímco u vysokoškolských studujících dominují projevy fyzického charakteru. Zdá se, že adolescenti se cítí více ohroženi jakýmikoliv útoky na svoji osobní integritu, na rozdíl od mladých dospělých, kteří se s verbálními komentáři dokáži snadněji vyrovnat či na ně dokonce zareagovat. K obdobným závěrům dospívají i zahraniční a další české výzkumy (Paludi 2006; Vohlídalová 2009).

Z výsledků ovšem také vyplývá, že mezi hodnocením abstrahovaných projevi̊ a hodnocením komplexních situací neexistuje bezprostřední vztah. Studující mají tendenci být v posuzování scénářu mírnější a v menší míře, než je tomu u hodnocení jednotlivých projevů, považovat chování za obtěžující. Baterii, $\mathrm{v}$ níž se studující vyjadřovali $\mathrm{k}$ tomu, zda jsou jednotlivé projevy obtěžující, můžeme chápat jako vyjádření jejich osobní definice genderově motivovaného a sexuálního obtěžování. Posuzování scénářů pak představuje aplikaci této osobní definice do reálného kontextu. Domníváme se, že benevolentnější hodnocení konkrétních situací vychází z toho, že se studující snaží zohlednit komplexitu reality, v níž je třeba zvažovat řadu dílčích faktorů a $\mathrm{v}$ níž se perspektivy jednotlivých aktérů obvykle liší. Na rozdíl od schematického popisu dílčího chování není v bohatosti reálné situace tak snadné určit, zda došlo k překročení institucionálně ukotvených hranic, př́ípadně zda pro překročení neexistují okolnosti, které by je částečně omlouvaly. Na základě tohoto zjištění můžeme usuzovat, že při hodnocení reálně pozorovaného chování, tj. mimo kontext výzkumu, by studující byli ještě více liknaví v označování takového chování za obtěžování. Čím komplexnější situace je, tím spíše jsou studující opatrní v jejím posuzování. Větší benevolentnost chlapců v porovnání s dívkami lze vysvětlit tím, že mají mnohem více vlastních zkušeností s obtěžováním dívek (ošahávání, sexuální narážky atd.), a proto jsou váhavější, když mají dané chování odsoudit.

\section{Závěr: od výzkumu do škol}

V našem výzkumu se potvrdilo, že studující středních škol mají četné zkušenosti s chováním, které náleží do definice genderově motivovaného a sexuálního obtěžování. Vysokoškoláci/ vysokoškolačky $\mathrm{v}$ předcházejícím šetření sice uváděli směrem ke středním školám vyšší výskyt, než $\mathrm{k}$ jakému jsme následně dospěli, ovšem tento rozdíl považujeme za logický. Lidé na vysokých školách jsou kognitivně i osobnostně zralejší, což jim dovoluje být vůči neadekvátnímu učitelskému chování kritičtější. To se může projevovat i zpětně při posuzování 
chování, na které vzpomínají. Navzdory tomuto posunu v míře kritičnosti však pro obě věkové skupiny studujících platí, že operují s relativně úzkou laickou/osobní definicí obtěžování. Za obtěžování považují zejména takové chování sexuální povahy, které má charakter quit-pro-quo (tj. něco za něco) a/nebo které ohrožuje tělesnou integritu člověka. V př́padě jemnějších forem projevování sexualizovaného zájmu a $\mathrm{v}$ prípadě užívání genderových stereotypů $\mathrm{k}$ zesměšnění či urážení má řada studujících o priřazení $\mathrm{k}$ definici pochybnosti. Studující tedy do obtěžování nezahrnují řadu projevů, které se nevztahují explicitně k sexualitě, nýbrž ,jen“ $\mathrm{k}$ genderové př́slušnosti. Podle nás se jedná zejména o důsledek nedostatečného povědomí o genderovém řádu a malé obeznámenosti s fenoménem sexuálního obtěžování (které chápeme jako součást genderově motivovaného obtěžování).

Redukovaná osobní definice má za následek, že studující uvádí výrazně menší výskyt zkušeností s obtěžováním, je-li použito jen jeho označení, než zkušeností s jednotlivými typy chování, které by pod definici „objektivně“ spadaly. Kromě toho má ale úzká definice vliv i na vnímání samotných projevů. Schopnost vnímat určité jevy se senzitivizuje, pokud jsou tyto jevy konceptualizovány a zvýznamněny. Zahraniční akční výzkumy ukazují, že jsou-li studující vedeni $\mathrm{k}$ tomu, aby o obtěžování systematicky uvažovali, vzrůstá jejich citlivost vůči takovému chování, které potenciálně charakteristiky obtěžování splňuje. Čím více informací studující mají, tím spíše jsou vůči obtěžujícímu chování citliví (Gruber a Smith 1995). Vazbu mezi vnímáním a označováním prokázal i náš výzkum. Studující, kteří určité chování označovali za obtěžování a byli viči němu kritičtí, měli zároveň s tímto chováním více zkušeností. Hloubku a směr kauzálního vztahu se nám sice prokázat nepodařilo, avšak domníváme se, že existuje spíše ve směru označení - vnímání, než opačně. Tuto hypotézu vysuzujeme i z překvapujících výsledků srovnávajících dívčí a chlapecké zkušenosti. Ukázalo se, že chlapci u řady projevů uvádí větší výskyt než dívky. To vyplývá zřejmě z toho, že dívky pokládají takové chování za natolik samozřejmé, že mu nepřikládají váhu, a zároveň že chlapci jsou genderovým řádem podporováni v produkci obtěžujícího chování, kterého si proto ve školním prostředí více všímají. Nicméně ty dívky, které operují s relativně robustní definicí obtěžování, uvádí také více zkušeností s tímto chováním.

Implikací této hypotézy $\mathrm{v}$ praktických opatřeních proti sexuálnímu obtěžování by mělo být, že studujícím budou nabízeny př́ležitosti ke konceptualizaci tohoto fenoménu. Na základě zahraničních projektů se proto ukazuje jako účinné zvyšovat pomocí osvětových kampaní i výuky informovanost vyučujících a studujících o obtěžování a šǐřji o genderové problematice $^{20}$ (Lipson 2001; Shakeshaft 2002; Paludi 2006). Efektivita takových aktivit ovšem závisí na zvolené formě. Zjištění našeho výzkumu totiž naznačují, že existuje rozpor v hodnocení abstrahovaných projevů a komplexních (reálných) situací. $Z$ toho vyplývá, že prevence by měla využívat zejména aktivní formy. Pokud jsou studujícím pouze předloženy informace, nemusí to být dostatečné, nebot' se tím nezaručuje, že studující budou schopni identifikovat sexuální obtěžování ve vlastním životě. Zdá se tedy vhodné využívat zejména aktivizační postupy a techniky zážitkové pedagogiky. Jedná se o metody, které cíleně působí

20 Současně s tím by se ovšem měly vyvíjet aktivity v dalších oblastech, konkrétně se doporučuje deklarovat nepřijatelnost obtěžujícího chování, vybudovat formální mechanismy pro ohlašování a řešení př́ipadů obtěžování, posilovat kvalitní sociální a pedagogické klima. 
na emocionální složku postoje vůči obtěžování, například příběhy umožňující identifikaci s hlavní postavou.

Jak hypotéza o dominantním vztahu mezi označováním a vnímáním, tak hypotéza o efektivitě aktivizačních metod jsou logickými vyústěními našeho výzkumu. Jejich platnost však není zcela prokázána. Zda a za jakých podmínek fungují, bychom rádi ověřili v některém $\mathrm{z}$ budoucích výzkumných šetření.

\section{Literatura}

ARVEY, Richard D.; CAVANAUGH, Marcie A. Using Surveys to Assess the Prevalence of Sexual Harassment: Some Methodological Problems. Journal of Social Issues, 1995, roč. 51, č. 1, s. 39-52. ISSN 1540-4560.

BÖRJESON, Lena; HÖJER, Mattias; DREBORG, Karl-Henrik; EKVALL, Tomas; FINNVEDEN, Göran. Scenario types and techniques: Towards a user's guide. Futures, 2006, roč. 38, č. 7, s. 723-739. ISSN 1652-5442.

BOURDIEU, Pierre. Nadvláda mužů. Praha: Karolinum, 2000. ISBN 80-7184-775-5.

CHRISLER, Joan C.; McCREARY, Donald R. Handbook of Gender Research in Psychology. London: Springer, 2010. ISBN 978-1-4419-1466-8.

CORR, Philip J.; JACKSON, Chris J. Dimensions of Perceived Sexual Harassment: Effects of Gender and Status/Liking of Protagonist. Personality and Individual Differences, 2001, roč. 30, č. 3, s. 525-539. ISSN 0191-8869.

FITZGERALD, Louise F.; GELFAND, Michele J.; DRASGOW, Fritz. Measuring Sexual Harassment: Theoretical and Psychometric Advances. Basic and Applied Social Psychology, 1995, roč. 17, č. 4, s. 425-445. ISSN 0197-3533.

FREIBERG, Jerome H. (ed.). School climate: Measuring, improving and sustaining healthy learning environments. Philadelphia, PA: Falmer Press, 1999. ISBN 978-0-7507-0642-1.

GRUBER, James E.; SMITH, Michael D. Women's Responses to Sexual Harassment: A Multivariate Analysis. Basic and Applied Social Psychology, 1995, roč. 17, č. 4, s. 543-562. ISSN 0197-3533.

KOSS, Mary P.; OROS, Chris J. Sexual Experiences Survey: A Research Instrument Investigating Sexual Aggression and Victimization. Journal of Consulting and Clinical Psychology, 1982, roč. 50, č. 3, s. 455-457. ISSN 0022-006X.

LENGNICK-HALL, Mark L. Sexual Harassment Research: A Methodological Critique. Personnel Psychology, 1995, roč. 48, č. 4, s. 841-864. ISSN 1744-6570.

LIPSON, Jodi (ed.). Hostile Hallways: Bullying, Teasing and Sexual Harassment in School. Washington, DC: American Association of University Women Educational Foundation, 2001. ISBN 1-879922-28-2.

NIELSEN, Morten B.; BJORKELO, Brita; NOTELAERS, Guy; EINARSEN, Stale. Sexual Harrasment: Prevalence, Outcomes, and Gender Differences Assessed by Three Different Estimation Methods. Journal of Aggression, Maltreatment \& Trauma, 2010, roč. 19, č. 3, s. 252-274. ISSN 1092-6771.

PALUDI, Michele A.; PALUDI, Carmen A. Academic and Workplace Sexual Harassment. London: Praeger, 1997. ISBN 9780791408292.

PIANTA, Robert C. Enhancing Relationships Between Children and Teachers. Washington, D.C.: American Psychological Association, 1999. ISBN 9781557987655.

PLAUT, Michael S. Sexual and Nonsexual Boundaries in Professional Relationships: Principles and Teaching Guidelines. Sexual and Relationship Therapy, 2008, roč. 23, č. 1, s. 85-94. ISSN 1468-1994. 
SADKER, David; SADKER, Myra; ZITTLEMAN, Karen R. Still Failing at Fairness. How Gender Bias Cheats Girls and Boys in School and What We Can Do About It. New York: Scribner, 2009. ISBN 1416552472.

SHAKESHAFT, Charol. Sexual Violence in Schools. In KOCH, J., IRBY, B. (eds.) Defining and Redefining Gender Equity in Education. Charlotte: Information Age Publishing, 2002, s. 117-132. ISBN 9781931576420.

SMETÁČKOVÁ, Irena; PAVLÍK, Petr. Sexuální obtěžování na vysokých školách: Teoretické vymezení, metodologický př́istup, výzkumné výsledky. Sociologický časopis, 2011, roč. 47, č. 2, s. 89-114. ISSN 0038-0288.

Statistická ročenka školstvi 2010/2011 - Výkonové ukazatele. Praha: Ústav pro informace ve vzdělávání, 2011. Dostupné na: www.uiv.cz.

TANGRI, Sandra S.; HAYES, Sharon M. Theories of sexual harassment. In O'DONOHUE, W. (ed.). Sexual Harassment, Theory, Research and Treatment. Boston: Allyn and Bacon, 1997, s. 112-128. ISBN 978-0-205-16412-7.

TIMMERMAN, Greetje. Sexual Harassment of Adolescents Perpetrated by Teachers and by Peers: An Exploration of the Dynamics of Power, Culture, and Gender in Secondary Schools. Sex Roles, 2003, roč. 48, č. 5-6, s. 231-244. ISSN 0360-0025.

UGGEN, Christopher; BLACKSTONE, Amy. Sexual Harassment as a Gendered Expression of Power. American Sociological Review, 2004, roč. 69, č. 1, s. 64-92. ISSN 1939-8271.

VOHLÍDALOVÁ, Marta. Sexuální obtěžování na vysoké škole. V ČR neexistující problém? Gender, rovné př́ležitosti, výzkum, 2009, roč. 10, č. 2, s. 20-28. ISSN 1213-0028.

WALSH, Margaret; DUFFY, Jim; GALLAGHER-DUFFY, Joanne. A More Accurate Approach to Measuring the Prevalence of Sexual Harassment Among High School Students. Canadian Journal of Behavioral Science, 2007, roč. 39, č. 2, s. 110-118. ISSN 0008-400X.

WINTERS, Jason, CLIFT, Robert J. W., MALONEY, Anne. Adult-Student Sexual Harassment in British Columbia High Schools. Journal of Emotional Abuse, 2004, roč. 4, č. 3-4, s. 177-196. ISSN $1540-4714$

\section{Autorka a autor}

Irena Smetáčková působí na Katedře psychologie Pedagogické fakulty UK v Praze.

Kontakt: irena.smetackova@pedf.cuni.cz

Petr Pavlik působí na Katedře genderových studií Fakulty humanitních studií UK v Praze.

Kontakt: petr.pavlik@seznam.cz 